\title{
Renewal of Basic Education Fund in Brazil: Disputes on Funding and Federal Distribution
}

\author{
Andressa Pellanda \\ University of São Paulo \\ Daniel Cara \\ University of São Paulo
}

The last few years have been ones of intense debate in the Brazilian National Congress about the Basic Education Fund (Fundeb) seeking ways for this temporary mechanism to become permanent and improved. Debates on privatization of education and on tax justice are key elements in these discussions. This article sets out to analyze discussions around the amount of financing for Fundeb, funding sources, federal decentralization, and privatization proposals, presenting the active interest groups advocating on different sides of the agenda.

Keywords: education financing, tax justice, interest groups, federal decentralization, privatization of education

\section{INTRODUCTION}

Among the main structural policies implemented for basic education in Brazil, the Fund for Maintenance and Development of Basic Education and Valorization of Education Professionals (Fundeb) is the most successful (Pinto, 2015; Cara \& Pellanda, 2017). This is the conclusion of research that we presented in 2017 at the Latin American Congress of Political Science (Alacip). In this research, we evaluated the design, implementation and monitoring of three major structural policies for basic education: Fundeb, the National Education Plan, and the Teachers' Salary Floor. Fundeb was the only one of the three policies to be fully implemented (Cara \& Pellanda, 2017). The Education Plans that have been provided for in the Federal Constitution since the re-democratization of Brazil in 1988 year have always been cornered by governments and only half of the states and municipalities manage to fulfill the Teachers' Salary Floor - today from R $\$ 2,886.24$ ( USD 525,85) for a 40-hour week.

Fundeb has had some clear success in terms of increasing enrollment but there are some continuing concerns about quality and about its sustainability. The Cost of Quality Education per Student (CAQ) mechanism, which calculates a quality standard in education, establishes the need for a much larger investment by the federal government than is provided today: from $10 \%$ of federal contribution to the Fund it is necessary to jump to $40 \%$ (BCRE, 2019). This is what is necessary to pay for that Teachers' Salary Floor for all education professionals, in a school with a minimum quality structure (BCRE, 2018).

Effective since 2006, Fundeb has an original expiration date in December 2020 and the last few years have been ones of intense debates in the National Congress for the transformation of Fundeb into a 
permanent fund, which is better resourced and with more effective mechanisms for collection and distribution of resources. The debates have not been homogeneous or easy. Vigorous arguments have emerged around the amount of financing, the sources of funds, the level of decentralization, the proposals for privatization, and the means to evaluate this policy. Parliamentarians, NGOs, academics, activists and private actors have all been involved in debating where does the money come from, where does the money go to and how to measure if it is working. In the process clear interest groups have emerged.

\section{MAPPING ACTORS AND MAIN POINTS OF DISPUTE}

There are two main groups involved in the fight for the future direction of Brazilian education (Pellanda, 2019; Chamber of Deputies, 2020) - one that supports the expansion of financing through tax justice and one that opposes extra financing and is premised on a minimalist view of the State, supporting privatization as a solution. See Appendix for the table.

Group 1 is formed primarily by representatives of subnational governments (states and large municipalities), NGOs, social movements, professional associations and research associations, as well as parliamentarians in opposition to the present Federal Government. This group argues for the need to guarantee minimum quality standards, through CAQ, with adequate investments for this purpose (with much higher complementation of the Union to state funds). It also argues for a genuinely redistributive system that takes into account student enrollments and inequalities, avoiding a situation where money is taken from a less poor state to give it to an even poorer one. Another concern of this first group relates to the evaluation system that is used - which needs to go beyond narrow test scores such as Basic Education Development Index (Ideb), which are very limited in measuring quality. Finally, this group asserts the importance of public money going to public education, resisting the use of vouchers that literature shows and are not efficient and do not advance quality (Ravitch, 2011; Ball, 2013; Treviño, 2018).

On the other hand, Group 2 is composed primarily of business representatives (such as the Todos Pela Educação coalition, a coalition of hundreds of companies and its foundations); deputies and senators linked to Jorge Paulo Lemann (the largest Brazilian businessman today); members of the Federal Government of Jair Bolsonaro; and representations of small wealthy municipalities in the south of the country. This group argues that Federal resourcing of Fundeb does not need to increase much, and that most financing should come from states and municipalities. They are also in favor of reallocating existing funds rather than allocating new funds and they prioritise distribution of resources based on the results of large-scale evaluations. Some members of this group (especially those connected to liberal parties - such as Tiago Mitraud from Partido Novo) also advocate the use of vouchers.

This second group represents private sector interests and has a minimalist view of the State and public policy. They promote a vision of education that falls below the standards already established by the low ceiling of existing policies. They are supportive of economic austerity and they are happy to see a stratified education system, tiered based on the ability to pay, leaving a very poor model for the poorest which would amount to little more than training children to fulfill cheap labour roles. This would violate the right to education and perpetuate the present unfair social system in Brazil, which is already recognised as one of the most unequal countries in the world (World Bank, 2018).

\section{PROCEEDINGS OF PEC 15/2015 AND POLITICAL ROUTE CHANGES}

The first draft of the proposal that Dep. Dorinha - rapporteur for PEC 15/2015 - presented, in September 2019 (Chamber of Deputies, 2019), offered some positive signs to the first group who advocate for increased resources for public education. The proposal resonated with those who are seeking tax justice and opposing privatisation and who want to see the government committed to better redistribution of resources. This draft text of course deeply dissatisfied Group 2 which includes the present presidency of the Chamber of Deputies (that is the driving force for neoliberal reforms and wider cuts to social services).

Group 2 did not wait long to press for major revisions and retreats. Maia, the President of the Chamber of Deputies threatened that "either the discussion of Fundeb in Congress will go to the real world or it will 
have to be stopped and frozen until 2020" (UOL, 2019). He complained about the influence of the teachers' lobby and asked for an 'expenses efficiency diagnoses' from Congresswoman Tábata Amaral (PDT-SP), the same person who stated that with USD 70 per student per month (USD 840 / year) it is possible to have quality education. She is author of the Amendment 03, with deputy Felipe Rigoni (PSB-ES), that argues for a much-reduced Union contribution to the Fund based on simplistic econometrics studies linked to large-scale assessments to financing per student (Chamber of Deputies, 2020). A combination of these actions and sustained pressure from Group 2 led to a second draft presented in March 2020 which reverse many of the positive elements in the first draft.

Despite all the compelling evidence presented on the need for greater investments by the federal government in basic education, the group arguing for a minimalist state seemed to have won. Even in the context of Covid the Brazilian National Congress maintained a ceiling on social spending - defying national and international recommendations (United Nations, 2020). This reflects a wider setback for human rights and for democracy in Brazil in recent years. For obvious reasons President Bolsonaro's Minister of Finance, Paulo Guedes, has the nickname 'scissor-hands' and he is surrounded by many other ultra conservative politicians. Equally worrying are a set of more polished actors who draw loosely on international theories and evidence to advance their ideological positions.

Despite the setbacks in the second draft of the law the good news is that Group 1 did not give up. Educational movements articulated on a massive scale, including four days of intense mobilization on social networks and online pressure on all parliamentarians. This national commotion made anyone who opposed more funding to Fundeb to appear to be against education itself, especially in a Covid-19 context - and this shifted the ground. In the Chamber of Deputies a victory was won that requires $23 \%$ of Federal resources to be allocated to Fundeb (up from 10\%), with the explicit inclusion of CAQ (to determine the costs needed for quality education) and a broader and more complex evaluation system and with a hybrid system for distribution of resources for public education ${ }^{1}$. All of these items were proposed by BCRE ${ }^{2}$, who led Group 1 advocacy work. After many struggles, on $25^{\text {th }}$ August 2020 the Fundeb text was finally approved unanimously in the Federal Senate. At last the fight for sustainable financing of public education has been won and Fundeb is now permanent and established in the constitution. There will be further struggles and intense debates ahead, for example to ensure effective implementation and regulation and to ensure that there is also action to deliver on tax reform. ${ }^{2}$

\section{ENDNOTES}

1. Access here to check on the final score table: https://www.camara.leg.br/presenca-comissoes/votacaoportal? reuniao $=59778$.

2. Access more information about BCRE's mobilization and articulation: https://br.noticias.yahoo.com/maisde-cinquenta-entidades-se-posicionam-a-favor-do-novo-fundeb-relatado-por-flavio-arns-144046411.html

3. Access here to check on Federal Government Tax Reform proposal: https://www.gov.br/ptbr/noticias/financas-impostos-e-gestao-publica/2020/07/governo-federal-entrega-primeira-parte-dareforma-tributaria-ao-congresso-nacional.

\section{REFERENCES}

Ball, S. (2013). Education, justice and democracy: The struggle over ignorance and opportunity. England: Center for Labor and Social Studies. Retrieved from https://link.springer.com/chapter/10.1007\%2F978-3-319-24699-4_14

BCRE. (2018). CAQi and CAQ in the National Education Plan: How much does public and quality education cost in Brazil? Brazilian Campaign for the Right to Education Editions.

BCRE. (2019). New Fundeb: The hybrid system and the right to education - access and quality. Study presented to the Special Committee of Fundeb of the Chamber of Deputies.

Cara, D., \& Pellanda, A. (2017, July 26-28). Entre a garantia legal e a do direito: Um panorama de três políticas públicas de educação no Brasil nos últimos dez anos. 9th Latin American Congress of 
Political Science, organized by the Latin American Association of Political Science (ALACIP). Montevideo.

Chamber of Deputies. (2019). Relatora apresenta versão preliminar para novo Fundeb; texto amplia participação da União. Agência Câmara de Notícias.

Chamber of Deputies. (2020). Substitutive Report to Fundeb. Special Commission to decide on the Proposed Amendment to Constitution no. 15-A, 2015. Brazil.

Fineduca. (2020). Não é hora de retroceder no Fundeb! - Nota da Associação Nacional de Pesquisa em Financiamento da Educação (Fineduca) sobre algumas tentativas, de última hora, de minar o esforço da Comissão Especial do Fundeb, coordenado pelo deputado Bacelar, presidente da Comissão, e pela deputada Profa. Dorinha Seabra Rezende, relatora, de construir um Fundeb permanente e que represente um ganho para a qualidade da educação brasileira.

Pellanda, A. (2019). Novo Fundeb: Quem é quem na disputa da Câmara dos Deputados? Campanha Nacional pelo Direito à Educação.

Pinto, J.M. (2015). O Fundeb na perspectiva do custo aluno qualidade. Em Aberto, 28(93). doi:http://dx.doi.org/10.24109/2176-6673.emaberto.28i93.2460

Ravitch, D. (2011). Life and death of the great American school system: How standardized tests and the market model threaten education. Porto Alegre: Sulina.

Todos pela Educação. (2019). Fontes de Recursos para a complementação da União.

Treviño, E., Mintrop, R., Villalobos, C., \& Ordenes, M. (n.d.). What Might Happen If School Vouchers and Privatization of Schools Were to Become Universal in the U.S.: Learning from a National Test Case-Chile. Boulder, CO: National Education Policy Center. Retrieved from http://nepc.colorado.edu/publication/chilean-voucher

United Nations. (2020). COVID-19: Brazil's irresponsible economic and social policies put millions of lives at risk, UN experts say.

UOL. (2019). Maia says that Fundeb debate hangs if not for the real world.

World Bank. (2018). Gini Index.

APPENDIX

TABLE 1

MAP OF TOPICS IN DISPUTE ON FUNDEB DISCUSSION IN THE CHAMBER OF DEPUTIES (PEC 15/2015)

\begin{tabular}{|c|c|c|c|}
\hline Topic & Defense & Actors & \\
\hline $\begin{array}{l}\text { Amount of } \\
\text { financing }\end{array}$ & $\begin{array}{l}40 \% \text { of complementation of the } \\
\text { Union to state funds, based on } \\
\text { CAQi calculs }\end{array}$ & $\begin{array}{l}1 . \\
2 . \\
3 . \\
4 . \\
5 . \\
6 . \\
7 . \\
7 .\end{array}$ & $\begin{array}{l}\text { Group } 1 \\
\text { Brazilian Campaign for the Right to } \\
\text { Education, } \\
\text { NGO Ação Educativa, } \\
\text { ActionAid Brazil, } \\
\text { National Association for Research in } \\
\text { Education Financing (FINEDUCA), } \\
\text { Luiz Freire Culture Center (CCLF), } \\
\text { Center for the Defense of Children and } \\
\text { Adolescents of Brazil Ceará (CEDECA-CE), } \\
\text { National Confederation of Education } \\
\text { Workers (CNTE) } \\
\text { Inter-Forum Movement for Early Childhood } \\
\text { Education in Brazil (Mieib), }\end{array}$ \\
\hline
\end{tabular}




\begin{tabular}{|c|c|c|}
\hline & & $\begin{array}{l}\text { 9. Movement of Landless Rural Workers } \\
\text { (MST), } \\
\text { 10. National Union of Municipal Education } \\
\text { Councils (Uncme), } \\
\text { 11. National Union of Municipal Education } \\
\text { Managers (Undime), } \\
\text { 12. State Governors' Forum, } \\
\text { 13. Presidents and vice-presidents of the } \\
\text { Education Commissions of the Legislative } \\
\text { Assemblies (Letter of June 7, 2019), } \\
\text { 14. National Mayors Front (big municipalities); } \\
\text { 15. APEOC Union (document of 05/06/2019), } \\
\text { 16. the senators who signed PEC 65/2019 } \\
\text { (Fundeb at Senate), authored by Sen. Davi } \\
\text { Alcolumbre (DEM-AP), president of the } \\
\text { Federal Senate, and Randolfe Rodrigues } \\
\text { (REDE-AP), leader of the opposition, } \\
\text { 17. the minority in the Chamber of Deputies, } \\
\text { under the leadership of Jandira Feghali } \\
\text { (PCdoB-RJ), } \\
\text { 18. the opposition in the Chamber of Deputies, } \\
\text { under the leadership of Alessandro Molon } \\
\text { (PSB-RJ), } \\
\text { 19. deputies Idilvan Alencar (PDT-CE), Rosa } \\
\text { Neide (PT-MT), Danilo Cabral (PSB-PE), } \\
\text { Sâmia Bonfim (PSOL-SP), Edmilson } \\
\text { Rodrigues (PSOL-PA), among others. }\end{array}$ \\
\hline & $\begin{array}{l}\text { at least } 10 \% \text { of } \\
\text { complementation of the Union } \\
\text { to state funds and then yielding } \\
\text { to at least } 15 \%\end{array}$ & $\begin{array}{l}\text { Group } 2 \\
\text { 1. deputies Felipe Rigoni (PSB-ES) and Tábata } \\
\text { Amaral (PDT-SP) - from Lemann Bench, } \\
\text { 2. Todos pela Educação, } \\
\text { 3. National Confederation of Municipalities } \\
\text { organizations (small municipalities), } \\
\text { 4. the Ministries of Education (which defended } \\
\text { a ceiling of } 15 \% \text { and not minimum) and } \\
\text { Economy. }\end{array}$ \\
\hline $\begin{array}{l}\text { Sources of } \\
\text { funds }\end{array}$ & $\begin{array}{l}\text { Taxation of large fortunes (tax } \\
\text { provided for in the Brazilian } \\
\text { Constitution of } 1988 \text {, not yet } \\
\text { regulated); federal resources } \\
\text { from royalties, special } \\
\text { participation and pre-salt social } \\
\text { fund; the collection of personal } \\
\text { income tax on interest and } \\
\text { dividends; as well as the } \\
\text { revision of the payment of the } \\
\text { public debt, considering that in } \\
2020 \text { the payment by the }\end{array}$ & $\begin{array}{l}\text { Group } 1 \\
\text { 1. Brazilian Campaign for the Right to } \\
\text { Education, } \\
\text { 2. NGO Ação Educativa, } \\
\text { 3. ActionAid Brazil, } \\
\text { 4. National Association for Research in } \\
\text { Education Financing (FINEDUCA), } \\
\text { 5. Luiz Freire Culture Center (CCLF), } \\
\text { 6. Center for the Defense of Children and } \\
\text { Adolescents of Brazil Ceará (CEDECA-CE), } \\
\text { 7. National Confederation of Education } \\
\text { Workers (CNTE) }\end{array}$ \\
\hline
\end{tabular}




\begin{tabular}{|c|c|c|}
\hline & $\begin{array}{l}\text { Federal Government of R } \$ \\
248.6 \text { billion (according to the } \\
\text { Annual Public Debt Financing } \\
\text { Plan 2020) is foreseen, an } \\
\text { amount that is equivalent to the } \\
\text { entire expense of R } \$ 250 \\
\text { billion in basic education from } \\
\text { state, municipal and federal } \\
\text { governments (estimated values } \\
\text { based on data from Siope / } \\
\text { FNDE and Finbra / STN for the } \\
\text { years } 2017 \text { and 2018). }\end{array}$ & $\begin{array}{l}\text { 8. Inter-Forum Movement for Early Childhood } \\
\text { Education in Brazil (Mieib), } \\
\text { 9. Movement of Landless Rural Workers } \\
\text { (MST), } \\
\text { 10. National Union of Municipal Education } \\
\text { Councils (Uncme), } \\
\text { 11. National Union of Municipal Education } \\
\text { Managers (Undime). }\end{array}$ \\
\hline & $\begin{array}{l}\text { Possibility of using } \\
\text { constitutional funds for regional } \\
\text { development; Petroleum } \\
\text { royalties; securitization of the } \\
\text { Union's active debt; Sectorial } \\
\text { Funds; Union Real Estate Fund; } \\
\text { Judicial recovery of resources } \\
\text { and judicial fines; and sale of } \\
\text { National Bank for Economic } \\
\text { and Social Development-PAR } \\
\text { shares. }\end{array}$ & $\begin{array}{l}\text { Group } 2 \\
\text { Todos Pela Educação. }\end{array}$ \\
\hline & $\begin{array}{l}\text { Possibility of using } \\
\text { constitutional funds for regional } \\
\text { development; resources from } \\
\text { complementary education } \\
\text { programs (discover them to } \\
\text { cover Fundeb). }\end{array}$ & $\begin{array}{l}\text { Group } 2 \\
\text { 1. Federal Government, } \\
\text { 2. Chamber of Deputies President, Rodrigo } \\
\text { Maia (DEM-RJ). }\end{array}$ \\
\hline $\begin{array}{l}\text { Form of } \\
\text { federative } \\
\text { distribution }\end{array}$ & $\begin{array}{l}\text { Hybrid system, which keeps the } \\
\text { distribution as it works today up } \\
\text { to } 10 \% \text {, preserving the current } \\
\text { distribution and, above } 10 \% \text { up } \\
\text { to } 40 \% \text { of complementation of } \\
\text { the Union, considers the } \\
\text { investments of states and } \\
\text { municipalities }\end{array}$ & $\begin{array}{l}\text { Group 1 } \\
\text { 1. Brazilian Campaign for the Right to } \\
\text { Education, } \\
\text { 2. NGO Ação Educativa, } \\
\text { 3. ActionAid Brazil, } \\
\text { 4. National Association for Research in } \\
\text { Education Financing (FINEDUCA), } \\
\text { 5. Luiz Freire Culture Center (CCLF), } \\
\text { 6. Center for the Defense of Children and } \\
\text { Adolescents of Brazil Ceará (CEDECA-CE), } \\
\text { 7. National Confederation of Education } \\
\text { Workers (CNTE) } \\
\text { 8. Inter-Forum Movement for Early Childhood } \\
\text { Education in Brazil (Mieib), } \\
\text { 9. Movement of Landless Rural Workers } \\
\text { (MST), } \\
\text { 10. National Union of Municipal Education } \\
\text { Councils (Uncme), }\end{array}$ \\
\hline
\end{tabular}




\begin{tabular}{|c|c|c|}
\hline & & $\begin{array}{l}\text { 11. National Union of Municipal Education } \\
\text { Managers (Undime). }\end{array}$ \\
\hline & $\begin{array}{l}\text { Total Year Student Value } \\
\text { (VAAT) concept, which which } \\
\text { burdens states and } \\
\text { municipalities more than the } \\
\text { Union }\end{array}$ & $\begin{array}{l}\text { Group } 2 \\
\text { 1. deputies Felipe Rigoni (PSB-ES) and Tábata } \\
\text { Amaral (PDT-SP) - from Lemann Bench, } \\
\text { 2. Todos pela Educação, } \\
\text { 3. National Confederation of Municipalities } \\
\text { organizations (small municipalities), } \\
\text { 4. the Ministries of Education (which defended } \\
\text { a ceiling of } 15 \% \text { and not minimum) and } \\
\text { Economy. }\end{array}$ \\
\hline \multirow[t]{2}{*}{$\begin{array}{l}\text { Policy } \\
\text { evaluation }\end{array}$} & $\begin{array}{l}\text { National Basic Education } \\
\text { Evaluation System (Sinaeb) }\end{array}$ & $\begin{array}{l}\text { Group 1 } \\
\text { 1. Brazilian Campaign for the Right to } \\
\text { Education, } \\
\text { 2. NGO Ação Educativa, } \\
\text { 3. ActionAid Brazil, } \\
\text { 4. National Association for Research in } \\
\text { Education Financing (FINEDUCA), } \\
\text { 5. Luiz Freire Culture Center (CCLF), } \\
\text { 6. Center for the Defense of Children and } \\
\text { Adolescents of Brazil Ceará (CEDECA-CE), } \\
\text { 7. National Confederation of Education } \\
\text { Workers (CNTE) } \\
\text { 8. Inter-Forum Movement for Early Childhood } \\
\text { Education in Brazil (Mieib), } \\
\text { 9. Movement of Landless Rural Workers } \\
\text { (MST), } \\
\text { 10. National Union of Municipal Education } \\
\text { Councils (Uncme), } \\
\text { 11. National Union of Municipal Education } \\
\text { Managers (Undime). }\end{array}$ \\
\hline & $\begin{array}{l}\text { Basic Education Development } \\
\text { Index (Ideb), with distribution of } \\
\text { resources linked to results }\end{array}$ & $\begin{array}{l}\text { Group } 2 \\
\text { 1. deputies Felipe Rigoni (PSB-ES) and Tábata } \\
\text { Amaral (PDT-SP) - from Lemann Bench, } \\
\text { 2. Todos pela Educação, } \\
\text { 3. National Confederation of Municipalities } \\
\text { organizations (small municipalities), } \\
\text { 4. the Ministries of Education (which defended } \\
\text { a ceiling of 15\% and not minimum) and } \\
\text { Economy. }\end{array}$ \\
\hline $\begin{array}{l}\text { Privatization } \\
\text { proposals }\end{array}$ & Vouchers & $\begin{array}{l}\text { Group } 2 \\
\text { Deputies Tiago Mitraud (NOVO-MG) and } \\
\text { Marcelo Calero (CIDADANIA-RJ), - from } \\
\text { Lemann Bench. }\end{array}$ \\
\hline
\end{tabular}

